\title{
Mutational Frequencies in Mycobacterial rpoB gene using GeneXpert/ MTB Rif Assay in Rifampicin Resistant patients at a tertiary care setting in Urban Sindh, Pakistan: Analysis from a Five-Year Period
}

\author{
Muhammad Alamgir ${ }^{1}$, Mehwish Sajjad ${ }^{2}$, \\ Mirza Saifullah Baig ${ }^{3}$, Muhammad Yahya Noori ${ }^{4}$
}

\begin{abstract}
Objectives: To assess the mutational frequencies in Mycobacterial $r p o B$ gene using GeneXpert/MTB Rif Assay in rifampicin resistant patients during 2013-2017 at a tertiary care setting in Urban Sindh, Pakistan. Methods: This Retrospective Descriptive Cross-Sectional Study was conducted at the TB laboratories, Ojha Institute of Chest Diseases, Dow University of Health Sciences. The record of 713 positive cases of Rifampicin Resistant Tuberculosis from January 2013 to December 2017 were analysed. These were diagnosed using GeneXpert $\circledast$ that detects mutations in the 81 base pair region of $r p o B$ gene with the help of five molecular probes A, B, C, D and E. All invalid and extra pulmonary samples were excluded.

Results: In total, 713 cases were found to be rifampicin resistant during the five-year period, among which $374(52.45 \%)$ were males while 339 (47.55\%) were females. Among the five standard probes A, B, C, D and $\mathrm{E}, \mathbf{9 7 . 4 8 \%}$ of the cases had a single mutation. Among these, mutations in Probe $\mathrm{E}(66.48 \%)$ were the most common, followed by Probe B (14.3\%) and Probe D (11.08\%). Only 13 cases $(1.82 \%)$ of double mutations and five cases $(0.7 \%)$ of triple mutations were detected.

Conclusion: The rpoB gene Probe E region 529-533 appears the most potent site for a mutation and development of rifampicin resistance in the $r p o B$ gene in Mycobacterium tuberculosis, that encodes the $B$-subunit of RNA polymerase. The most affected age-group in both males and females is 19-45 Years.
\end{abstract}

KEYWORDS: Mycobacterium Tuberculosis, GeneXpert, Rifampicin resistance, rpoB gene, Probe Mutations.

How to cite this:

doi: https://doi.org/10.12669/pjms.37.4.3875

Alamgir M, Sajjad M, Baig MS, Noori MY. Mutational Frequencies in Mycobacterial rpoB gene using GeneXpert/MTB Rif Assay in Rifampicin Resistant patients at a tertiary care setting in Urban Sindh, Pakistan: Analysis from a Five-Year Period. Pak J Med Sci. 2021;37(4):1151-1154. doi: https://doi.org/10.12669/pjms.37.4.3875

This is an Open Access article distributed under the terms of the Creative Commons Attribution License (http://creativecommons.org/licenses/by/3.0), which permits unrestricted use, distribution, and reproduction in any medium, provided the original work is properly cited.

1. Muhammad Alamgir, M. Sc.

Lab Technician, Ojha Institute of Chest Diseases,

2. Mehwish Sajjad, MBBS, M. Phil.

Lecturer, Department of Pathology,

Dow International Medical College,

3. Mirza Saifullah Baig, MBBS, FCPS.

Assistant Professor of Pulmonology, Ojha Institute of Chest Diseases,

4. Muhammad Yahya Noori, MBBS, Ph. D, MBA, M. Sc.

Associate Professor of Microbiology, Department of Pathology, Dow International Medical College,

1-4: Dow University of Health Sciences, Karachi, Pakistan.

Correspondence

Muhammad Yahya Noori,

Department of Microbiology, Associate Professor of Pathology, Dow International Medical College, Dow University of Health Sciences, Karachi, Pakistan.

E-mail: y.noori@duhs.edu.pk

* Received for Publication:

* Revision Received:

* Revision Accepted:
November 13, 2020

March 10, 2021

March 18, 2021

\section{INTRODUCTION}

Drug Resistant Tuberculosis (DR-TB) is a worldwide health problem. Not only it is difficult to treat but also the cost of treatment of DR-TB is much higher than the ordinary disease. It is unfortunate that Pakistan has the fourth highest prevalence of multi drug resistance and more than 15000 cases of DR-TB emerge every year. ${ }^{1}$

With the traditional Drug-Sensitivity Testing (DST) replaced by rapid molecular diagnostics, new areas of scientific inquiry are emerging in TB diagnostics and management. The GeneXpert MTB/RIF Assay is among the most popular tools, endorsed and recommended by the $\mathrm{WHO}^{2}$ that detects rifampicin resistance in patient samples 
by detecting mutations in the rpoB gene. It uses a Real time PCR based closed system and detects changes in $r p o B$ gene that encodes $\beta$ subunit of RNA polymerase, the site where rifampicin binds and inhibits the polymerase from transcribing and stopping the protein production. It uses five different overlapping probes $\mathrm{A}, \mathrm{B}, \mathrm{C}, \mathrm{D}$ and $\mathrm{E}$ to detect mutations in codons from 507-511, 511518, 518-523, 523-529 and 529-533, respectively. ${ }^{3}$ These probes assist in differentiating among the wild type and mutated forms that are associated with rifampicin resistance. Different types of mutations have different effects on the bacterial physiology and survival, hence knowing the types, frequencies and geographical correlates of these mutations may influence future interventions.

As the first step, this study aims to determine the relative frequencies of different regional mutations through assessing the relative frequencies of associated probes for various $r p o B$ gene mutations by GeneXpert MTB/RIF Assay.

\section{METHODS}

It was retrospective cross-sectional study based on the diagnostic records of the Tuberculosis Laboratories of Dow University of Health Sciences at Ojha Institute of Chest Diseases. Ethical approval was obtained from the Institutional Review Board of Dow University of Health Sciences. All cases that were received and tested positive for rifampicin resistance on GeneXpert, during the five-year-period from $1^{\text {st }}$ January, 2013 to $31^{\text {st }}$ December, 2017 were included.

Data were analysed from 713 cases. Records were deidentified for names and only demographic details about age and gender were noted. All cases with invalid and extra pulmonary samples were excluded.

Samples were processed as per manufacturer's instructions. Briefly, Xpert Sample Reagent (SR) was added to unprocessed sputum sample in a 2:1 ratio into a $15 \mathrm{ml}$ centrifuge tube and

Table-I: Gender-wise age distribution of rifampicin-resistant patients.

\begin{tabular}{lccccc}
\hline & $0-18$ & $19-45$ & $>45$ & Not & \multirow{2}{*}{ Total } \\
& Years & Years & Years & Available* & \\
\hline Males & 36 & 243 & 79 & 16 & 374 \\
Females & 69 & 212 & 49 & 9 & 339 \\
Total & 105 & 455 & 128 & 25 & 713 \\
\hline
\end{tabular}

* Patients, for whom age records were missing. incubated at room temperature for 15 minutes. During incubation period, the samples were mixed by inverting the tubes gently 2 times every 5 minutes. Then $2.0 \mathrm{ml}$ of liquefied sample was transferred to Xpert Cartridge (Ver 3.0) and loaded into GeneXpert IV machine and observed for results. ${ }^{4}$

Mutational frequencies were calculated for each probe. Data were tabulated in Microsoft Excel. Chi square test was applied using SPSS Version 24. Results were considered significant with p-value less than 0.05 .

\section{RESULTS}

Among the 713 cases analyzed for the study, $374(52.45 \%)$ were males and $339(47.55 \%)$ were females. The age distribution is summarized in Table-I.

The most common group among the subjects was between 19 and 45 years. in both the genders. Gender-wise data were tabulated (Table-II) in relation to different probes from the 363 male and 332 female patients, who were resistant to rifampicin patients and the region examined by Probe $\mathrm{E}$ was found to be the most commonly affected by the mutation, followed by that of Probe B. Chi-square test showed differences to be statistically non-significant.

These data were further stratified for age group and probe type and it was observed that the age group 19-45 years had the highest number of mutations in the Probe E region. Data are summarized in Table-III.

A few patients $(2.5 \%)$ with double and triple mutations were also found. Although the number was small, but interestingly some combinations were completely absent. Data are summarized in Table-IV.

Table-II: Gender-wise distribution of rifampicinresistance patients in relation to different regions of rpoB gene detected through Probes A, B, C, D \& E.

\begin{tabular}{cccc}
\hline Probe & \multicolumn{3}{c}{ Mutations } \\
\hline & Male & Female & p-value \\
\hline A & 15 & 14 & \\
B & 56 & 46 & \\
C & 6 & 5 & 0.98 \\
D & 42 & 37 & \\
E & 244 & 230 & \\
& 363 & 332 & \\
\hline
\end{tabular}


Table-III: Age-wise distribution of rifampicin-resistance patients in relation to different regions of rpoB gene detected through Probes A, B, C, D and E.

\begin{tabular}{cccccc}
\hline & 0-18 Years & 19-45 Years & >45 Years & Not Available & Totals \\
\hline A & 1 & 17 & 8 & 3 & 29 \\
B & 14 & 71 & 16 & 1 & 102 \\
C & 4 & 5 & 2 & 0 & 11 \\
D & 9 & 48 & 19 & 3 & 79 \\
E & 75 & 302 & 81 & 16 & 474 \\
\hline Totals & 103 & 443 & 126 & 23 & 695 \\
\hline
\end{tabular}

*Patients, for whom age records were missing.

Table-IV: Age-wise distribution of rifampicin-resistant patients having double or triple mutations in relation to different regions of rpoB gene detected through Probes A, B, C, D and E.

\begin{tabular}{|c|c|c|c|c|c|}
\hline & $0-18$ & $19-45$ & $>45$ & Not Available & Totals \\
\hline $\mathrm{AB}$ & 0 & 2 & 0 & 2 & 4 \\
\hline $\mathrm{AD}$ & 1 & 6 & 0 & 0 & 7 \\
\hline DB & 0 & 2 & 0 & 0 & 2 \\
\hline EAD & 1 & 2 & 2 & 0 & 5 \\
\hline Totals & 2 & 12 & 2 & 2 & 18 \\
\hline
\end{tabular}

\section{DISCUSSION}

Drug resistant Tuberculosis (DR-Tb) is among serious public health issues worldwide. ${ }^{5}$ It is considered a major threat to the developing countries. Pakistan has extremely high burden of tuberculosis patients, who are constantly facing the threat of developing drug resistance. ${ }^{5}$ Many diagnostic techniques are used for detection of $\mathrm{TB}$ and drug resistance, which now include rapid diagnostic tools such as GeneXpert. These can save precious time, which would otherwise be wasted through traditional methods to detect drug resistance. ${ }^{6}$ Due to limited requirements of infrastructure and technical expertise, GeneXpert is emerging as a particularly useful tool in the rural settings, which detects mutations in the $81 \mathrm{bp}$ region of $3534 \mathrm{bp} \mathrm{rpoB}$ gene with the help of five molecular beacons. ${ }^{78}$ The five probes used for this purpose have been shown to have different frequencies of mutations resulting in rifampicin resistance in studies from Pakistan, India, Bangladesh and other regions of the world, though mutations in probe $\mathrm{E}$ were found to be the highest in all studies, which is consistent with our results. ${ }^{9-17}$

Though the results from GeneXpert, do not provide the exact point of mutation in the rpoB gene, a number of sequencing studies show that codon
531, which is covered by Probe E is among the most common spots of mutation. Other specific mutations recognized in different studies were codon 526 (covered by Probe D) and 516 (covered by Probe B). The most conserved region, that has been found among different studies was the Probe $\mathrm{C}$ region, which is also consistent with our own findings. ${ }^{9-17}$ The mutation at codon 531, changes Serine to Leucine, changing the polar $\mathrm{R}$ group of Serine with the non-polar $\mathrm{R}$ group of Leucine, resulting in development of resistance to rifampicin. ${ }^{18}$ The highest frequency of this particular mutation may be explained by high mutagenic potential of Serine with downstream positive selection favouring this change, as it is considered as "a mutational hotspot" and is the among the most frequently replaced amino acids. ${ }^{19}$ Further bioinformatics-based studies based upon this finding might provide interesting insights into this high frequency of mutation.

Some mutation combinations were also found where there were two or more mutations involving regions covered by probes, $\mathrm{A}, \mathrm{B}$ : A, D: $\mathrm{B}, \mathrm{D}$ and $\mathrm{A}, \mathrm{D}, \mathrm{E}$, however, they were considerably less frequent, probably owing to the result of decreased selection pressure, once the organism has already acquired drug resistance through one of the mutations. 
Limitations of the study: Though our study had the limitations of not identifying the particular mutation directly through PCR and sequencing, however, the knowledge about probe frequency can be used to screen for the trends of evolving rifampicin resistance in Mycobacterium tuberculosis. In addition our other limitations include sideby-side comparison with culture and drug susceptibility testing, to rule out false negative and positive results for GeneXpert.

\section{CONCLUSION}

This study showed that the mutations in the Probe E region are disproportionately common, while the age-group 19-45 was the most commonly affected age-group among the rifampicin-resistant patients.

Acknowledgement: The study is based on data generated by routine testing at the lab of Ojha Institute of Chest Diseases. The Lab is maintained by the joint contribution of Dow University of Health Sciences and National and Provincial Tuberculosis Control Programs.

\section{Grant Support \& Financial Disclosures: None,}

\section{Conflict of Interest: None.}

\section{REFERENCES}

1. World Health Organization, Regional Office for the Eastern Mediterranian. Tuberculosis-Pakistan [Internet]. WHO. Updated 2020 cited 2019. Available from http://www.emro. who.int/pak/programmes/stop-tuberculosis.html

2. Lawn SD, Nicol MP. Xpert ${ }^{\circledR}$ MTB/RIF assay: Development, evaluation and implementation of a new rapid molecular diagnostic for tuberculosis and rifampicin resistance. Future Microbiol. 2011;6(9):1067-1082. doi: 10.2217/fmb.11.84

3. Steingart KR, Schiller I, Horne DJ, Pai M, Boehme CC, Dendukuri N. Xpert ${ }^{\circledast}$ MTB/RIF assay for pulmonary tuberculosis and rifampicin resistance in adults. Cochrane Database Syst Rev. 2014(1):CD009593. doi: 10.1002/14651858.CD009593.pub3

4. World Health Organization. Xpert MTB/RIF Implementation Manual. Technical and operational 'how-to' practical considerations. Geneva. WHO Press; 2014.

5. World Health Organization. Global tuberculosis report 2020. Geneva, Switzerland: 2020.

6. Reddy R, Alvarez-Uria G. Molecular epidemiology of rifampicin resistance in Mycobacterium tuberculosis Using the GeneXpert MTB/RIF assay from a rural setting in India. J Pathog. 2017;2017:6738095. doi: 10.1155/2017/6738095

7. Miller LP, Crawford JT, Shinnick TM. The rpoB gene of Mycobacterium tuberculosis. Antimicrob Agents Chemother. 1994; 38(4):805-811. doi: 10.1128/ AAC.38.4.805

8. El-Hajj HH, Marras SA, Tyagi S, Kramer FR, Alland D. Detection of rifampin resistance in Mycobacterium tuberculosis in a single tube with molecular beacons. J Clin Microbiol. 2001;39(11):41314137. doi: 10.1128/JCM.39.11.4131-4137.2001

9. Ullah I, Shah AA, Basit A, Ali M, Khan A, Ullah U, et al Rifampicin resistance mutations in the 81 bp RRDR of rpoB gene in Mycobacterium tuberculosis clinical isolates using Xpert MTB/ RIF in Khyber Pakhtunkhwa, Pakistan: A retrospective study. BMC Infect Dis. 2016;16:413. doi: 10.1186/s12879-016-1745-2
10. Kaur R, Jindal N, Arora S, Kataria S. Epidemiology of rifampicin resistant tuberculosis and common mutations in rpoB gene of Mycobacterium tuberculosis: A retrospective study from six districts of Punjab (India) Using Xpert MTB/RIF Assay. J Lab Physicians. 2016;8(2):96-100. doi: 10.4103/0974-2727.180789

11. Mengal MZ, Ali H, Asmat R, Naeem M, Abbas F, Samad A, Mustafa MZ, et al. Detection of mutations in 81-bp rifampin resistance determining region (RRDR) of rpoB gene in Mycobacterium tuberculosis using GeneXpert MTB/RIF in Clinical Specimens from Quetta, Pakistan. Pak J Zool. 2021;53(1). doi: 10.17582/journal.pjz/20190522060512

12. Mohajeri P, Sadri H, Farahani A, Norozi B, Atashi S Frequency of mutations associated with rifampicin resistance in Mycobacterium tuberculosis strains isolated from patients in West of Iran. Microb Drug Resist. 2015;21(3):315-319. doi: $10.1089 / \mathrm{mdr} .2014 .0075$

13. Mboowa G, Namaganda C, Ssengooba W. Rifampicin resistance mutations in the $81 \mathrm{bp}$ RRDR of rpoB gene in Mycobacterium tuberculosis clinical isolates using $\operatorname{Xpert}(\mathrm{R}) \mathrm{MTB} / \mathrm{RIF}$ in Kampala, Uganda: a retrospective study. BMC Infect Dis. 2014;14:481. doi: 10.1186/1471-2334-14-481

14. Zaw MT, Emran NA, Lin Z. Mutations inside rifampicinresistance determining region of $\mathrm{rpoB}$ gene associated with rifampicin-resistance in Mycobacterium tuberculosis. J Infect Public Health. 2018;11(5):605-610. doi: 10.1016/j.jiph.2018.04.005

15. Qazi O, Rahman H, Tahir Z, Qasim M, Khan S, Ahmad Anjum A, et al. Mutation pattern in rifampicin resistance determining region of rpoB gene in multidrug-resistant Mycobacterium tuberculosis isolates from Pakistan. Int J Mycobacteriol. 2014;3(3):173-177. doi: 10.1016/j.ijmyco.2014.06.004

16. Tajbakhsh A, Ghasemi F, Mirbagheri SZ, Momen Heravi M, Rezaee M, Meshkat Z. Investigation of the rpoB Mycobacterium tuberculosis in North-East of Iran. Iran J Pathol. 2018;13(4):429437.

17. Herrera L, Jimenez S, Valverde A, Garcia-Aranda MA, Saez-Nieto JA. Molecular analysis of rifampicin-resistant Mycobacterium tuberculosis isolated in Spain (1996-2001). Description of new mutations in the rpoB gene and review of the literature. Int J Antimicrob Agents. 2003;21(5):403-408. doi: 10.1016/s09248579(03)00036-0

18. Thirumurugan R, Kathirvel M, Vallayyachari K, Surendar K, Samrot AV, Muthaiah M. Molecular analysis of rpoB gene mutations in rifampicin resistant Mycobacterium tuberculosis isolates by multiple allele specific polymerase chain reaction in Puducherry, South India. J Infect Public Health. 2015;1;8(6):619625. doi: $10.1016 /$ j.jiph.2015.05.003

19. Creixell P, Schoof EM, Tan CS, Linding R. Mutational properties of amino acid residues: Implications for evolvability of phosphorylatable residues. Philosophical Transactions of the Royal Society B. Biol Sci. 2012;19;367(1602):2584-2593. doi: $10.1098 /$ rstb.2012.0076

\section{Author Contribution:}

MA: Performed the GenXpert/MTB Rif Assay and recorded the data.

MS: Wrote the first draft, compiled and tabulated data.

SB: Conceived the idea, provided clinical supervision, Edited the manuscript.

MYN: Conceived the idea, designed the project, provided laboratory and overall supervision, prepared the final draft of the manuscript. He is also responsible for the study. 